\title{
STEM in Fashion Design: The Roles of Creative Self-Efficacy and Epistemic Curiosity in Creative Performance
}

\author{
Jon-Chao Hong ${ }^{1,2}$, Jian-Hong Ye ${ }^{1,2^{*}}$, Jing-Yun Fan ${ }^{3}$ \\ ${ }^{1}$ Department of Industrial Education, National Taiwan Normal University, TAIWAN \\ 2 Institute for Research Excellence in Learning Sciences, National Taiwan Normal University, TAIWAN \\ ${ }^{3}$ Department of Fashion Design, Tainan University of Technology, TAIWAN
}

Received 18 May 2018 - Revised 25 December 2018 - Accepted 24 Febuary 2019

\begin{abstract}
Integrated learning of STEM (science, technology, engineering, and mathematics) has become a challenge in the field of technical education. To understand the effect of STEM learning, in this study, we first identified the components of STEM in relation to bag design, then asked students to learn STEM knowledge as they designed bags. In this context, we explored how learners' creative self-efficacy (CSE) related to two types of epistemic curiosity (EC) (i.e., interest type and deprivation type) and reflected the STEM knowledge they acquired and their creative performance (i.e., novelty, utility, and aesthetics). The data were subjected to confirmatory factor analysis with structural equation modeling. The results revealed that CSE was positively related to two types of EC, and knowledge acquired was positively related to creative performance. The indirect correlates between CSE and knowledge acquired, EC and creative performance, and CSE and creative performance were positively mediated by other constructs. The implication of this research is that integrating STEM into the study of fashion design can improve students' creative performance.
\end{abstract}

Keywords: creative self-efficacy, epistemic curiosity, fashion design, STEM

\section{INTRODUCTION}

The subjects of science, technology, engineering, and mathematics, known integratively as STEM, have been essential to preparing the American workforce for future roles (Aladé et al., 2016; Langdon et al., 2011; Worsham, Clevenger, \& Whealan-George, 2016). STEM courses are often viewed as difficult and are sometimes unrelated to reality due to the traditional separations into the four disciplines that were erected with the initiation of STEM education. However, collective STEM education refers to any program in which there is an overt assimilation of concepts from more than one of the STEM disciplines (Satchwell \& Loepp, 2002). To learn STEM integratively, students need to be involved in hands-on STEM activities to make the connection between the four areas of domain knowledge (Bybee, 2010; León, Núñez, \& Liew, 2015).

The development of STEM courses has been quite diverse over the past more than 10 years, such as Fan and Yu (2017) and Sullivan and Bers (2016), which use robots as the basis for the development of STEM courses, while Ward, Clarke, and Horton (2014) taught STEM knowledge on the theme of plants. Zollman (2012) develops STEM literacy courses to enhance learners' recognition of STEM knowledge. Wai, Lubinski, and Benbow (2009) emphasized the importance of spatial capabilities in STEM knowledge development, Harrison and Parks (2017) integrated STEM knowledge into the writing curriculum, Miller and Roehrig (2018) developed STEM courses based on aboriginal culture, while Hall and Miro (2016) helped students to construct STEM knowledge in a topic-oriented learning method.

Project design related to STEM requires students to engage in six processes (i.e., problem identification, knowledge searching, ideation, analysis of ideas, testing and refinement, and implementation constraints) and behaviors (i.e., doing hands-on activities and communicating with group members) (Markham, 2003).

(C) 2019 by the authors; licensee Modestum Ltd., UK. This article is an open access article distributed under the terms and conditions of the Creative Commons Attribution License (http://creativecommons.org/licenses/by/4.0/). \tcdahong@gmail.com \kimpo30107@yahoo.com.tw (*Correspondence) \jingyun0308@gmail.com 


\section{Contribution of this paper to the literature}

- This the first study in incorporating STEM into leather bag design curriculum.

- This study found that STEM knowledge learning plays a key role in creative performance in the domain of fashion design.

- Knowledge fosters creative performance, and epistemic curiosity supports knowledge inquiry.

Designing products is a complex, multifaceted problem-solving activity involving various cognitive abilities, including imagination and creativity (Zeisel, 2006). However, few studies have focused on analyzing the learning effect of STEM in design-based learning. Previous studies have shown that, regardless of children's positive attitude toward science, there has been a decline in the interest of adolescents and adults in science (Bybee, 2010). Thus, in this study, we applied a project design course extended to college students studying fashion design to integrate the application of the four domains of knowledge and to explore the correlates between individual dispositions.

An important aspect of creativity is curiosity, Berlyne (1960) divided curiosity into perceptual curiosity (PC) and epistemic curiosity (EC). PC is caused by sensory stimulation, and EC is caused by a different idea, belief, or attitude. Given its essential role in human cognitive development, epistemic curiosity has been shown to positively predict creative performance (Mussel, 2013). Considering the broader literature on curiosity (Berlyne, 1960, 1966; Harrison et al., 2011; Litman \& Silvia, 2006), in this study, we adapted the distinction proposed by Litman and Silvia (2006) of two types of EC, namely interest-type (I-type EC), which refers to curiosity associated with interest in exploring unfamiliar topics and learning something new, and deprivation-type (D-type EC), which refers to curiosity related to the desire to reduce uncertainty and resolve gaps in one's understanding. In this study, we applied these two types of EC to explore the contribution to creative cognition of having students spend more time seeking out and gathering ideas or knowledge during the stages of design (Warr \& O'Neill, 2005) in the context of fashion design by utilizing STEM knowledge to develop creative solutions to fulfill the students' design assignments.

Recent assertions have combined curricula with hands-on design activities as pedagogical tools to teach STEMrelated topics (Workosky \& Willard, 2015). In project design, they should search for new knowledge or reflect on their prior knowledge, actively apply it to solve problems, and finally, construct their own knowledge (Han, Capraro, \& Capraro, 2016). However, Zhang (2019) posited that "hands-on" also needs "inquiry" to inspire students to apply knowledge in order to construct their knowledge. That is, students are expected to construct their own knowledge through STEM activities with problem-solving activities in project design.

Design \& Technology (D\&T) has much to offer STEM education, and it presents opportunities for "doing"based activities (Moye et al., 2014; Williams, Jones, \& Bunting, 2015), where students are engaged in practical problem solving, and as such it is a logical subject area through which to deliver "True STEM education" (Gomez \& Albrecht, 2013, p. 8). Bell (2016) posited that STEM engages with the ongoing supporting design value and purpose, and stressed that it must be placed within a school-based D\&T curriculum. Given the alignment of D\&T within the curriculum, the increased importance of STEM education that may potentially offer an opportunity for fashion design to be implemented in technological schools. Accordingly, this study focused on a fashion design course, bag design, which has the most enrollments in a technological college in Taiwan.

Research has shown that self-efficacy beliefs play an important role in STEM education, because self-efficacy refers to the initial beliefs before a perceived setback or challenge has occurred in project design learning (van Aalderen-Smeets \& Walma van der Molen, 2018). In particular, improving students' STEM-related self-efficacy would consequently increase the probability that students will engage in STEM learning (van Aalderen-Smeets \& Walma van der Molen, 2018). In addition, Claxton et al. (2006) stated that curiosity influences the formulation of design imagination, due to human curiosity being the original force that nurtures design imagination. However, in project design, the role of curiosity has been largely overlooked within STEM in relation to creative performance (Huang \& Li, 2015). This fact gave us an interest in understanding how a design school can cultivate students' creative self-efficacy to practice their epistemic curiosity in STEM, and how it would affect their creative performance.

\section{RESEARCH BACKGROUND}

\section{STEM and Fashion Design}

STEM education combines the subjects of science, technology, engineering, and mathematics as a unit, and then integrates the disciplines of STEM. A cohesive interdisciplinary learning paradigm of STEM is favored over a STEM focused one (Bakhshi, Hargreaves, \& Mateos-Garcia, 2013). A new educational pedagogy is required, which expands the traditional epistemology toward a design epistemology (Cross, 2006), indicating that STEM requires a 
move away from a focus on explicit knowledge and static curricular units towards more "connected learning" to enhance students' creative performance (Ito et al., 2013). Additionally, hands-on activities as part of STEM lead students to think of problems more concretely and help them try various strategies (Kaldi et al., 2011; Lou et al., 2011). Thus, students in fashion design are required to practice hands-on activities with knowledge of STEM.

The US Bureau of Labor Statistics' Occupational outlook handbook (OOH) (2019) states that the work of fashion designers content involved in the design of clothing, accessories, and footwear includes design drawing, pattern design, material knowledge, and other professional knowledge. Fashion designers should be able to explain their design concepts. Design drawings, printing design, material knowledge, and other professional knowledge can correspond to engineering, mathematics, science, and so on. The domain knowledge of fashion design is highly correlated with the fields of science, technology, engineering, and mathematics (Hathcock et al., 2015). Ashby, Shercliff, and Cebon (2007) highlighted that working with materials is usually coupled with a series of technological processes. In the technological process, designers have to take a large number of factors into account, such as physical properties, mechanical properties, impact on the environment, and so on. Accordingly, adapting Ashby et al.'s (2007) ideas, this study incorporated STEM into leather bag design.

Regarding the ingredients of STEM knowledge related to design, knowledge of the properties of various materials (e.g., leather and other material properties, including weight, color, being waterproof or breathable, etc.) is categorized as science knowledge. Knowledge related to graphic drawing, material processing (e.g., computer graphics, leather processing, etc.), and tool use (e.g., 3D printing, leather carving, laser engraving, laser cutting, digital printing, hand tools, sewing machine operation, etc.) is considered as technological knowledge. Knowledge of human ergonomic issues and engineering design processes (e.g., design of ergonomics for strap width and length, handle thickness, backpack length and width; cardboard pattern, notches, the double unit in the pleated design, the election skin, and tailoring, sewing and other bag-making process expertise; computer bag pattern making, etc.), and the material process stability and alignment (e.g., leather tanning and dyeing, etc.) are taken as engineering knowledge, and finally, knowledge of size and geometry measurements (e.g., angle measurement, proportional conversion, volume calculation, geometry concepts, etc.) is categorized as mathematics knowledge.

The "transfer in pieces" theory (Lobato, 2012; Wagner, 2006, 2010) proposes that learning transfer emerges from the gradual accumulation of smaller elements of knowledge, rooted in particular contexts and gradually refined to extend to a widening circle of situations. This incremental refinement of learning is highly individual and is sensitive to contextual variations (Cheng, 2016). In line with this, fashion design related to STEM need not be general and broad, but can be content-independent. If this perspective is correct, then fashion design may contribute to this "transfer in pieces" with STEM, which may result in diverse changes in individual creative performance.

\section{Creative Performance Assessment}

There are many existing creativity performance assessments tests. First, there is the Guilford Battery Creativity Test (1967), which measures fluency, flexibility, novelty, elaboration, and sensitivity. Second is the Torrance Test of Creative Thinking (TTCT) (Torrance, 1966), which has been used to assess the characteristics of fluency, flexibility, novelty, elaboration, inventiveness, and penetration. Kim (2006) posited a question on the usage of creativity tests and suggested that the creativity value can be adjusted for particular contexts. Thus, the context of fashion design at the college level, in which students are involved in STEM creative thinking including the novelty, atheistic, and utility dimensions, was the focus of this study.

\section{RESEARCH HYPOTHESES AND MODEL}

\section{Relationship between Creative Self-Efficacy and Epistemic Curiosity}

Self-efficacy is the belief in one's capability to achieve desired tasks and is about one's capability to control one's own behavior and to influence events affecting oneself (Bandura, 1997). Another concern of self-efficacy beliefs is thought to be experience-dependence (Caprara et al., 2008). In line with this, Tierney and Farmer (2002) highlighted that individuals' creative self-efficacy (CSE) is "the belief that one has the ability to produce creative outcomes" (p. 1138). When individuals believe that they can produce creative outcomes, self-efficacy should be considered as creative self-efficacy (Karwowski, 2011).

According to epistemic curiosity theory, I-type EC refers to individuals actively wanting to explore new things, and to accepting more outside stimuli. D-type EC refers to individuals, when encountering events that cannot be categorized into an existing category of knowledge or when facing complex problems, taking the initiative to solve the problem (Litman \& Jimerson, 2004; Litman, 2010). I-type EC and D-type EC correspond to different learning objectives. I-type EC aims to absorb more new knowledge, whereas D-type EC is based on doubt, and aims to solve problems. In the "design-led educational innovation" (Wright \& Wrigley, 2019), which requires a deeper 
understanding of knowledge and skills, students' mindsets require curiosity to practice in educational and real-life contexts (World Economic Forum, 2015).

Curiosity and self-efficacy have a positive correlation (Jeraj \& Maric, 2013; Jovanović \& Brdaric, 2012). Karwowski (2012) reported that curiosity has a significant positive relationship with CSE. As curiosity during the design process is the original trigger of design imagination and is relevant to strong efficacy (Wu, 2002), the correlates between CSE and the two types of EC in fashion design were hypothesized as follows:

H1: Creative self-efficacy is positively related to I-type EC.

H2: Creative self-efficacy is positively related to D-type EC.

\section{Relationship between Epistemic Curiosity and Knowledge Acquired}

Epistemic Curiosity is conceived as driving exploration and has been defined as the "desire for knowledge that motivates (learning) new ideas" (Litman, 2008, p. 1586). Lauriola et al. (2015) stated that epistemic curiosity (EC) is the motive to seek, obtain, and make use of new knowledge. They also suggested that "I-type EC corresponds to fun, carefree and optimistic approaches to learning, while D-type EC reflects greater thoughtfulness and caution regarding knowledge-search" (Lauriola et al., 2015, p. 202). Regarding these two different functions of EC, how knowledge learning in STEM related to fashion design can be affected was hypothesized as follows:

H3: I-type EC is positively related to knowledge acquired.

H4: D-type EC is positively related to knowledge acquired.

\section{Relationship between Knowledge Acquired and Creative Performance}

Knowledge can facilitate mental processes through active associations. Associations can change in time according to the changes in one's state of needs, emotions, surroundings, and so on, and can enable thinking, reasoning, adapting, and behaving intelligently (Duch, 2007). That is, all mental activities depend on knowledge that can be applied to many various and new situations that lead to generating new ideas (Horzyk, 2014). Creativity is defined as the development of ideas to make products that are perceived as unique, novel, relevant, and useful (Finke, Ward, \& Smith, 1992). Creativity and learning have a mutually supportive relationship with each other (Beghetto, 2016; Karwowski, 2017). Additionally, Khedhaouria, Montani, and Thurik (2017) found that knowledge sourcing behaviors play a central role in fostering creativity. Moreover, if learning activities involve embodied creativity practices and realistic exercises that would improve knowledge acquisition (Sawyer, 2015), then an activity such as fashion design would be a way to see how the knowledge learned can affect creative performance. Our hypotheses are as follows:

H5: Knowledge acquired is positively related to novelty.

H6: Knowledge acquired is positively related to utility.

H7: Knowledge acquired is positively related to aesthetics.

\section{Relationship between Creative Self-Efficacy and Knowledge Acquired Mediated by Epistemic Curiosity}

Curiosity can improve learners' learning attitudes and learning achievement (Goldberg et al., 2015), and has a positive correlation with self-efficacy (Gulten et al., 2011). That is, the role of epistemic curiosity might function as a mediator because previous research has suggested that individual traits are strong predictors of epistemic curiosity (Fleischhauer et al., 2010), which in turn ensures better learning (Kang et al., 2009; Mussel, 2013). How epistemic curiosity plays the mediating role in the relationship between creative self-efficacy and knowledge acquired was hypothesized as follows:

H8: Creative self-efficacy is positively related to knowledge acquired mediated by epistemic curiosity.

\section{Relationship between Epistemic Curiosity and Creative Performance Mediated by Knowledge Acquired}

Individuals with a high level of I-type EC curiosity are predisposed to seek out novelty because exposure to new information provides them with feelings of interest and excitement (Litman, 2005). Hardy III, Ness, and Mecca (2017) highlighted that this tendency "is well suited to early stage creative problem solving, which requires that individuals gather a wide range of information relevant to the problem that they can use in later stages of creative problem solving to generate and evaluate new ideas" (p. 231). Gajda, Beghetto, and Karwowski (in press) found more extended and exploratory interactions in the positive association classroom that would enhance the development or refinement of ideas. Thus, seeking a wide range of knowledge or ideas associated with feeling 
excited should be beneficial to creative performance. How I-type EC is related to creative performance was hypothesized as follows:

H9: I-type EC is positively related to novelty mediated by knowledge acquired.

H10: I-type EC is positively related to utility mediated by knowledge acquired.

H11: I-type EC is positively related to aesthetics mediated by knowledge acquired.

Unlike I-type EC, behaviors associated with D-type EC are related to individuals responding to changes in their surroundings, led by the development of feelings of competence and mastery (White, 1959). According to the information-processing theory, the problem-focused nature of D-type EC should prove more useful in the late stage of the creative process. That is, individuals with higher D-type EC will be more motivated to develop more ideas in terms of idea evaluation and the implementation stage of practical performance (Hardy III et al., 2017). However, Hardy III et al. (2017) reported that D-type EC (i.e., curiosity associated with deprivation factors) was found to be unrelated to creative performance when solving a complex marketing problem. Thus, how D-type EC affects creative performance was hypothesized as follows:

H12: D-type EC is positively related to novelty mediated by knowledge acquired.

H13: D-type EC is positively related to utility mediated by knowledge acquired.

H14: D-type EC is positively related to aesthetics mediated by knowledge acquired.

\section{Relationship between Creative Self-Efficacy and Creative Performance Mediated by Epistemic Curiosity and Knowledge Acquired}

The confidence of creativity can influence the type of achievement goals one decides to pursue (Dweck \& Leggett, 1988; Dweck, 2000); inversely, a growth mindset should influence the type of achievement goals students pursue so as to enhance their competence (Martin, 2015). That is, a growth mindset, perceived interest, and effort exerted are the elements of epistemic curiosity which are directly positively influenced by creative self-efficacy and which have a positive influence on learning achievement (Puente-Díaz \& Cavazos-Arroyo, 2017). Byrge and Tang (2015) studied the effect of embodied creativity training on trainees' creative self-efficacy and creative production, and found that there was a positive relationship between creative self-efficacy and creative production. Karwowski (2011) also found that there was a positive relationship between Polish secondary students' CSE and their creative ability. Thus:

H15: Creative self-efficacy is positively related to creative performance mediated by epistemic curiosity and knowledge acquired.

\section{Research Model}

Self-compassion promotes adaptive responses to difficult present life experiences. For example, it can increase motivation to make amends and to avoid repeating mistakes (Johnson \& O'Brien, 2013), and has been associated with goal reengagement, intrinsic motivation, personal initiative, mastery goals, and adaptive coping (Shapira \& Mongrain, 2010). According to self-compassion, how fashion design represents personal abilities (e.g., self-efficacy) that individuals copy difficult situations by practicing epistemic curiosity in the use STEM knowledge to create something was integrated as this research model (Figure 1). 


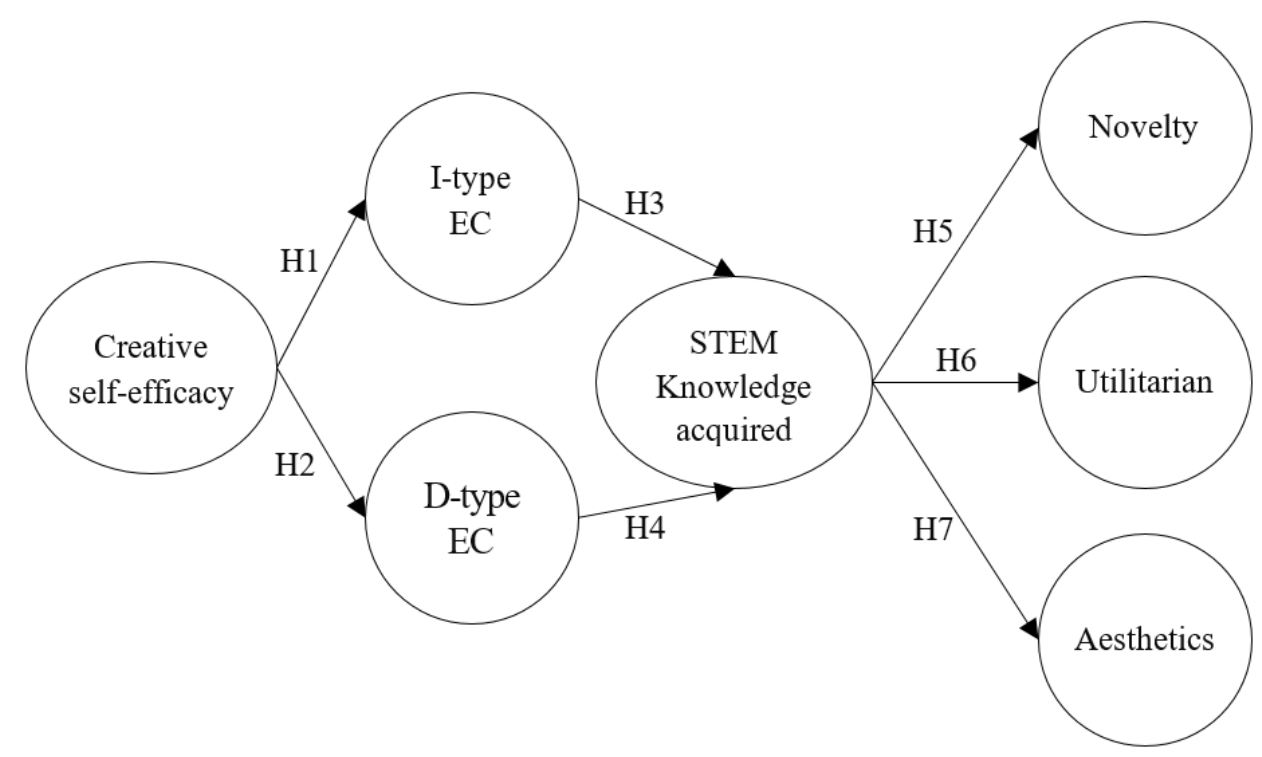

Figure 1. Research model

\section{RESEARCH DESIGN}

\section{Domain Knowledge Verification of STEM in Bag Design}

Bag design is a fundamental course for those students majoring in fashion design. In this study, we therefore attempted to investigate how those students could learn knowledge related to STEM when taking a bag design course. In order to validate the meaning and categorization of the related STEM knowledge, we invited five domain (i.e., fashion design) experts to review the content proposed by the researchers. Then, three panel discussions were organized to modify the meaning and categorization to reach agreement. Eventually, five items in each of the four STEM categories were validated, making a total of 20 items for the pre- and post-test.

An example of a science test item is: Which type of skin has the best air penetration (a: animal fabric, b: PU, c: PVC). A sample technology test item is: On what occasions should you use a computer sewing machine to sew bags? (a: to sew a multilayer bag, b: to sew on the logo, c: to sew the wrapping). An example engineering test item is: How can you keep the distance consistent from beginning to end when using a sewing machine to sew sheepskin? (a: by using two hands to stretch the ductility of the sheepskin to avoid deformation, b: by marking the stitching line, c: by using super glue to stabilize the stitching movement). A sample mathematics test item is: If the leather of PVC piping covering's width is set to $7 / 16$ inch, what is the most appropriate size ? (a: 7/8 inch $\times 1$ inch, b: 1 inch $\times 1$ inch, c: $6 / 8$ inch $\times 1$ inch).

\section{Procedure}

Bag design is one of the fashion design courses that has been most popularly taken in a technological college located in southern Taiwan. Vogt (2007) confirmed that this trend of purposive sampling was the most common form of sampling, and it remains true in contemporary social science research. Thus, by adopting the purposive sampling method, this study located target samples from freshmen and sophomores who took the bag design course.

This 4-week experimental research was then conducted. In the first week, the participants were introduced to the concept of STEM and how it corresponds to the field of fashion design knowledge (e.g. the application and characteristics of bag materials belong to science, bag processing techniques and tools are applied to science and technology, bag structure reinforcement and strap size of the best ratio belongs to the engineering, The measurement and unit conversion of each part of the bag is converted into mathematics) and finally when design how to link STEM and the fashion design professional knowledge, such as bag material characteristics, processing technology, structural design, dimensional measurement, printing design encountered mutual constraints.

In the second and third weeks, the participants were guided in self-directed learning of bag design to understand what STEM knowledge applied in their bag design by Internet searching. If they still had difficulty applying STEM knowledge to their bag design, the teachers would provide explanations via email. In the fourth week, the participants completed their bag designs (see Appendix A) and presented them for assessment of their 
creative performance by the teachers. Finally, the questionnaires were administered to the participants after their presentation.

\section{Participants}

In this study, using purposive sampling of a fashion design department, freshmen and sophomores were selected as the participants. Data of 197 participants were collected. After removing 38 invalid samples, 159 useful returns with $80.7 \%$ data were used for the statistical analysis. Of these, 19 were male students and 140 female, 77 were freshmen and 82 were sophomore students, and the average age was 20.1 years old.

\section{Measurement Questionnaire}

To develop the research scales, experts familiar with both the creativity literature and the creative simulation used in the present study rated a subset of fashion design on a 5-point scale. On these scales, the participants were asked to report how they "generally feel" in reference to a series of statements. Responses were given on a 5-point Likert scale ranging from 1 (almost never) to 5 (almost always).

Creative self-efficacy measure: This construct was adapted from previous studies (e.g., Li \& Wu, 2011; Robbins \& Kegley, 2010; Wang, Zhang, \& Martocchio, 2011), and included: self-rating, others' perceptions of your general creativity abilities. This self-rating of creative expression included 10 items.

Epistemic curiosity measure: The sub-dimensions of epistemic curiosity were measured using scales developed by Litman and colleagues (Litman, 2005, 2008; Litman \& Jimerson, 2004; Litman \& Spielberger, 2003). Five items assessed I-type EC and five assessed D-type EC for the participants to self-rate their perceptions in fashion design settings.

Creative performance measure: Consistent with the recommendations of Besemer and O'Quin (1999) and Christiaans (2002), and in line with common practice in the broader creativity literature, the creative performance of design was evaluated based on the design novelty, atheistic, and utility dimensions.

\section{DATA ANALYSIS}

\section{Creative Performance Analysis}

To assess students' creative performance, three professional teachers of fashion design, a fashion design scholar, and two fashion industry experts were involved in analyzing three components of the students' bag product design: novelty, utility, and aesthetics. The three teachers discussed the criteria of the three creative performances until they fully understood the criteria for measuring each scale. The assessment of novelty focused on the style innovation, meaning that the design is rarely seen in the marketplace, where the greater the rarity, the higher the points for novelty. The assessment of utility focused on the function of design; for aesthetics, the assessment was based on the homogeneity and symmetry of color or size interfacing, for example.

At the beginning of the assessment process, all of the students' product designs were rated. Then, to compare their consistency, the ratings of the three teachers were compared and rationalized until they agreed on a score. Finally, the three teachers repeated this process until a consistent interrater result of above $95 \%$ was reached, based on Kendall's coefficient of agreement analysis. A Kendall's coefficient of 0.9 or higher is considered very good, and means that the appraisers used the same standard when assessing the product design. The score result used the spearman rank correlation to analyze the results of the assessment inter-rater reliability (Stolarova et al., 2014).

\section{Item Analysis}

Applying first-order confirmatory factor analysis (CFA) to test internal validity of items, Table 1 shows that the threshold of $\chi^{2} /$ df should be less than 5; RMSEA should be less than 0.08; GFI and AGFI should be higher than 0.8; plus, items where the residual value is over 0.5 could be removed from the original questionnaire (Hair, Black, Babin, \& Anderson, 2010). Thus, the remaining items were kept in the questionnaire; the items for Creative selfefficacy were reduced from 8 to 4 , the items for I-type EC were reduced from 5 to 4 , and those for D-type EC were reduced from 5 to 4 . 
Table 1. First-order confirmatory factor analysis

\begin{tabular}{ccccc}
\hline overall model fit & Critical value & Creative self-efficacy & I-type EC & D-type EC \\
\hline$\chi^{2}$ & --- & 1.961 & 2.303 & 4.731 \\
\hline $\mathrm{df}$ & --- & 2 & 2 & 2 \\
\hline$\chi^{2} / \mathrm{df}$. & $<5$ & .098 & .152 & 2.366 \\
\hline $\mathrm{RMSEA}$ & $<.10$ & .000 & .031 & .093 \\
\hline $\mathrm{GFI}$ & $>.90$ & .994 & .993 & .986 \\
\hline $\mathrm{AGFI}$ & $>.90$ & .969 & .963 & .93 \\
\hline
\end{tabular}

Table 2. Reliability and validity analysis

\begin{tabular}{|c|c|c|c|c|}
\hline Items & M & SD & $\mathbf{F L}$ & $t$ value \\
\hline \multicolumn{5}{|l|}{ Creative self-efficacy } \\
\hline \multicolumn{5}{|l|}{ Mean=3.737, SD=.588, Cronbach's $\alpha=.855, \quad C R=.902, \quad A V E=.698$} \\
\hline 1. As long as I work hard, I can solve difficult problems during the creation process. & 3.76 & .716 & .846 & 66.269 \\
\hline 2. If I encounter challenges in the creation process, I still have a solution. & 3.67 & .68 & .876 & 68.14 \\
\hline $\begin{array}{l}\text { 3. When setting the creative theme, I will compare the different methods of creation and } \\
\text { choose the most suitable implementation. }\end{array}$ & 3.81 & .716 & .789 & 67.029 \\
\hline 4. In the creative process, when I made big mistakes, I still did not give up. & 3.71 & .706 & .828 & 66.301 \\
\hline \multicolumn{5}{|l|}{ I-type EC } \\
\hline 1. I enjoy exploring new ideas when I find new ways to design bags. & 4.09 & .732 & .917 & 70.377 \\
\hline 2. I find it fascinating to generate new ideas in design drawing. & 3.99 & .746 & .923 & 67.381 \\
\hline 3. When I see an unusual bag design, I will ask someone how it works. & 3.92 & .771 & .781 & 64.077 \\
\hline 4. I would like to find out more about bag design to improve my design. & 3.9 & .739 & .868 & 66.495 \\
\hline \multicolumn{5}{|l|}{$\begin{array}{cc} & \text { D-type EC } \\
M e a n=3.601, \quad S D=.567, & \text { Cronbach's } \alpha=.83 \\
\end{array}$} \\
\hline 1. I think for a long time when I encounter problems in bag design. & 3.53 & .673 & .81 & 66.227 \\
\hline 2. When designing bags, problems keep me awake thinking. & 3.52 & .692 & .791 & 64.172 \\
\hline 3. If I cannot overcome a problem in bag design, I usually work harder until I can solve it. & 3.58 & .706 & .852 & 63.91 \\
\hline 4. I cannot take a rest until I work out the problems when I design bags. & 3.77 & .695 & .808 & 68.319 \\
\hline
\end{tabular}

Table 3. Construct Discriminative Validity

\begin{tabular}{cccc}
\hline Constructs & Creative self-efficacy & I-type EC & D-type EC \\
\hline Creative self-efficacy & $\mathbf{( . 8 5 3 )}$ & & \\
\hline I-type EC & .585 & $\mathbf{( . 8 7 4 )}$ & $\mathbf{( . 8 1 5 )}$ \\
\hline D-type EC & .494 & .506 & .364 \\
\hline Knowledge acquired & .395 & .342 & .417 \\
\hline Novelty & .446 & .487 & .458 \\
\hline Utility & .513 & .565 & .388 \\
\hline Aesthetics & .54 & .53 & \\
\hline
\end{tabular}

The external validity of the study was to assess whether the scope of the study can extend to other participants and context (Cor, 2016), if the $t$ value (critical ratio) is greater than $3\left(p^{* * *}<.001\right)$, the discriminative power is considered to be significant. Table 2 shows that the $t$ value is higher than $63.91\left(p^{* * *}<0.001\right)$, which indicates that all items are different, and all items are able to determine the degree of response of different samples (Green \& Salkind, 2004).

\section{Reliability and Validity Analysis}

We used Cronbach's a and Composite Reliability (CR) to test reliability. Hancock and Mueller (2006) recommended that the Cronbach's a value should be higher than .7. Fornell and Larcker (1981) recommended that CR should be higher than 0.7. Validity can be tested by averaging Variance Extracted (AVE) and Factor Loading. They also said that the AVE value should be higher than 0.5, and Hair et al. (2012) said that Factor Loading should be higher than 0.6. Table 2 shows that all values met these thresholds, and thus the reliability and validity of the research measurement were acceptable.

The square root of the AVE of each construct was larger than the correlation coefficient of other constructs, and representatives had differentiated validity (Chin, 1998). In this study, Table 3 indicates that the correlation coefficient of each construct is smaller than the square root of the AVE value, indicating that all the constructs of this study had differentiated validity. 
Table 4. Knowledge acquired from pre-test to post-test

\begin{tabular}{ccccc}
\hline & $\mathbf{N}$ & $\mathbf{M}$ & SD & \multicolumn{1}{c}{ t } \\
\hline Pre-test & 159 & 13.742 & 2.393 & 1.6715 \\
\hline Post-test & 159 & 17.245 & $-26.24{ }^{\star \star \star}$ \\
\hline
\end{tabular}

Table 5. Creative performance analysis

\begin{tabular}{ccccc}
\hline & Novelty & Utility & Aesthetics & Creative performance \\
\hline M & 3.321 & 3.291 & 3.663 & 10.275 \\
SD & .65 & .637 & .6275 & 1.805 \\
\hline
\end{tabular}

\section{RESULTS}

The analysis was conducted using IBM SPSS 23.0 to analyze the differences, reliability, and validity. Furthermore, partial least squares (PLS) analysis was used to analyze the structural equation modeling.

\section{Knowledge Acquired in STEM}

In this study, we compared the pre-test and post-test to identify the knowledge learned during the experiment. The statistical results revealed that the improvement in STEM was 3.503 totally with $t=26.24, p<.001$ for the 159 samples, as shown in Table 4.

\section{Creative Performance Scoring}

Based on the domain experts' inter-rating, the average scores of novelty, utility, and aesthetics were 3.321, 3.291, and 3.663 respectively, as shown in Table 5.

\section{Path Analysis}

Given the parameter-to-sample size ratio, in this study, we used SmartPLS to determine that path analysis was more appropriate in this situation than structural equation modeling (MacCallum, Browne, \& Sugawara, 1996). The total and specific indirect effects were examined to identify the primary pathways responsible for the observed effects.

In spite of I-type EC and D-type EC being significantly correlated to Creative performance (novelty, utility, and aesthetics), the D-type EC for Creative performance of the correlation coefficient was significantly lower than the I-type EC. Therefore, it was deduced that I-type EC is more useful for Creative performance, and D-type is more useful for design creativity. The Creative self-efficacy for I-type EC was 36.3\%. and for D-type EC it was $25.2 \%$. The STEM knowledge acquired for novelty was $22.3 \%$, for utility it was $20.6 \%$, and for aesthetics, it was $22.4 \%$. In addition, creative self-efficacy had positive indirect effects on novelty, utility, and aesthetics, as shown in Figure 2 and Table 6. 


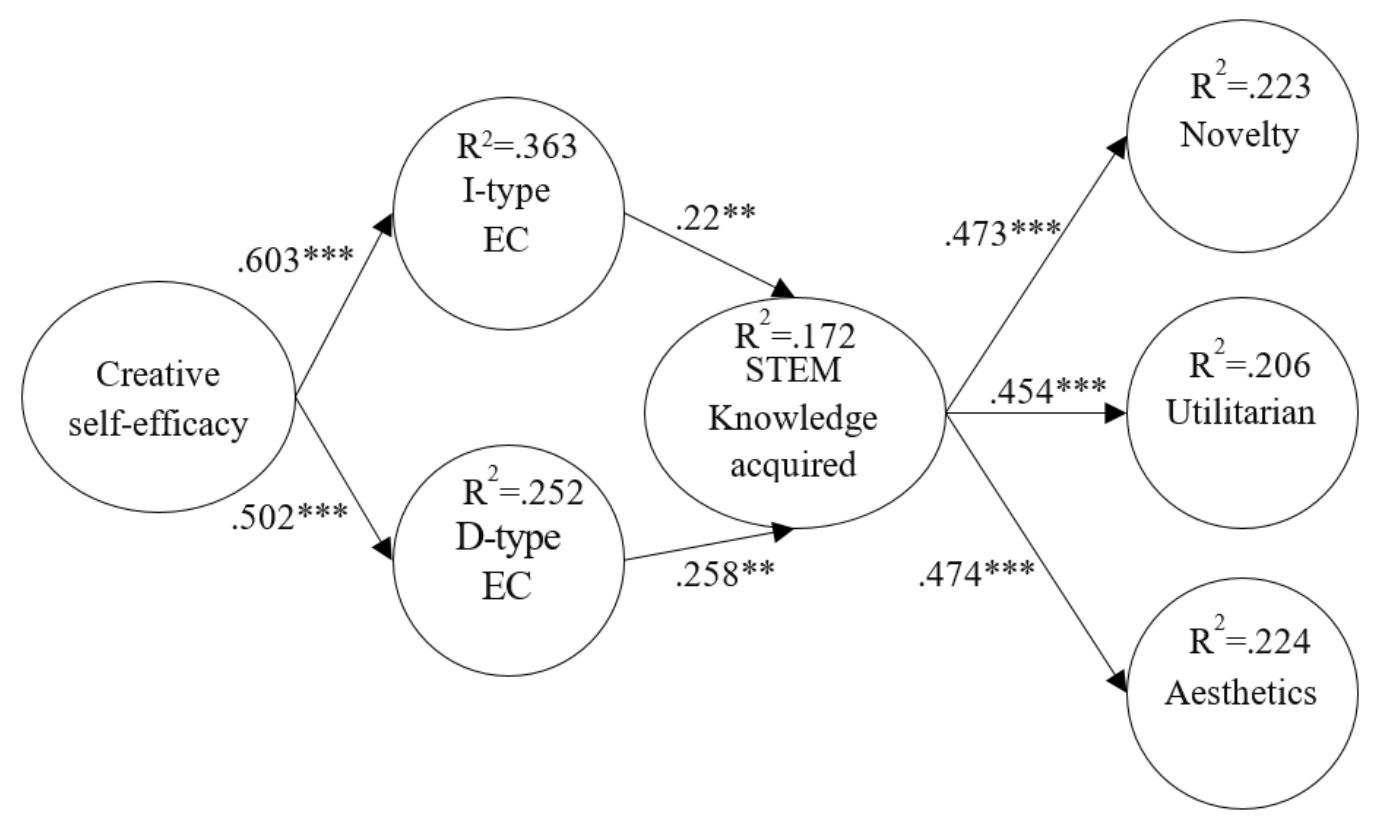

Figure 2. Verification of the research model

Table 6. Direct and indirect effect analysis

\begin{tabular}{|c|c|c|c|c|c|c|c|c|}
\hline \multirow[t]{2}{*}{ Constructs } & \multicolumn{2}{|c|}{ Creative self-efficacy } & \multicolumn{2}{|c|}{ I-type EC } & \multicolumn{2}{|c|}{ D-type EC } & \multicolumn{2}{|c|}{ Knowledge acquired } \\
\hline & $\boldsymbol{\beta}$ & $95 \% \mathrm{Cl}$ & $\boldsymbol{\beta}$ & $95 \% \mathrm{Cl}$ & $\beta$ & $95 \% \mathrm{Cl}$ & $\beta$ & $95 \% \mathrm{Cl}$ \\
\hline \multicolumn{9}{|l|}{ Direct effect } \\
\hline I-type EC & $.603^{* * *}$ & {$[.495, .785]$} & & & & & & \\
\hline D-type EC & $.502^{\star \star \star}$ & {$[.426, .759]$} & & & & & & \\
\hline $\begin{array}{l}\text { Knowledge } \\
\text { acquired }\end{array}$ & & & $.22^{\star *}$ & {$[.049, .411]$} & $.258^{* *}$ & {$[.038, .469]$} & & \\
\hline Novelty & & & & & & & $.473^{\star \star \star}$ & {$[.354, .581]$} \\
\hline Utility & & & & & & & $.454^{\star \star \star}$ & {$[.328, .566]$} \\
\hline Aesthetics & & & & & & & $.474^{\star \star \star}$ & {$[.185, .444]$} \\
\hline \multicolumn{9}{|c|}{ Indirect effect } \\
\hline $\begin{array}{l}\text { Knowledge } \\
\text { acquired }\end{array}$ & $.191^{\star *}$ & {$[.191, .434]$} & & & & & & \\
\hline Novelty & $.08^{\star \star}$ & {$[.08, .227]$} & $.022^{\star}$ & {$[.022, .222]$} & $.014^{*}$ & {$[.014, .228]$} & & \\
\hline Utility & $.071^{\star \star}$ & {$[.071, .227]$} & $.019^{*}$ & {$[.019, .213]$} & $.013^{*}$ & {$[.013, .221]$} & & \\
\hline Aesthetics & $.04^{\star *}$ & {$[.04, .18]$} & $.013^{*}$ & {$[.013, .159]$} & $.009^{*}$ & {$[.009, .17]$} & & \\
\hline
\end{tabular}

\section{DISCUSSION}

Creative performance is considered the most essential value in fashion design (Clinton \& Hokanson, 2012), where knowledge fosters creative performance, and epistemic curiosity supports knowledge inquiry. Thus, it is necessary to assess students' emotional states and creative performance after courses to understand the actual effect of the instruction (Daly, Mosyjowski, \& Seifert, 2014). This study therefore examined the correlates from the perspective of creative self-efficacy. Table 2 shows that the averages of CSE $(M=3.737, S D=.588)$, I-type EC $(M=$ $3.973, S D=.667)$, and D-type EC $(M=3.601 S D=.567)$ were all above 3.0, indicating that those participants had high levels of emotional states. Thus, we tested how the affective factors related to the behavioral factors in terms of creative performance. Briefly, the results of this study indicated that those constructs were all positively related. More details are elaborated as follows.

Beeftink et al. (2012) posited that creative self-efficacy can positively pave a way for successfully designing something new. In this study, I-type EC (interest) refers to the individual actively wanting to explore new approaches and accepting more ideas from outside stimuli. D-type EC (deprivation) refers to the individual encountering a fashion design that needs them to search for knowledge to solve complex problems. More specifically, in the process of fashion design, I-type EC may help students to think about the form or graphic design; on the other hand, D-type EC may encourage students to search for knowledge to solve design problems, such as 
human ergonomics, or utility. However, Jeraj and Maric's (2013) study showed that there was a significant positive relationship between EC and self-efficacy. Supporting their reports, in this study it was revealed that CSE was positively related to two types of EC, and $\mathrm{H} 1$ and $\mathrm{H} 2$ were positively supported.

According to Lauriola et al.' (2015) study, EC is the motive to seek and make use of new knowledge. In fashion design, such as hand bag design, students need more STEM knowledge, including material properties and process methods, human ergonomics, and the mathematics involved in measurement. By comparing the pre- and posttests, the results indicated that the students did in fact learn STEM knowledge. Moreover, it was found that the correlation between the two types of epistemic curiosity and STEM knowledge acquired was positive; hypotheses 3 and 4 were therefore positively supported.

Creativity and learning have a mutually supportive relationship with each other (Beghetto, 2016; Karwowski, 2017). Learning activity facilitates creative performance if it involves embodied creativity practices and realistic exercises that improve active and constructivist learning (Sawyer, 2015). Kim (2006) suggested that the creativity value can be adjusted for a particular context, whereas, for fashion design at the college level, students are involved in creative thinking involving the novelty, atheistic, and utility dimensions. As such, fashion design is an appropriate domain in which to see how learning can affect creative performance; in line with this, the results of this study showed that H5, H6, and H7 were positively supported.

Curiosity has a positive correlation with learners' self-efficacy (Gulten et al., 2011); moreover, curiosity can improve learners' learning attitudes and learning achievement (Goldberg et al., 2015). Fleischhauer et al. (2010) posited that the role of EC might function as a mediator; that is, individual self-efficacy is a strong predictor of EC, which in turn ensures better learning (Kang et al., 2009; Mussel, 2013). Hartnett, Malzahn, and Goldsmith (2014) found that through hands-on making, students' epistemic curiosity would be evoked and they would be more willing to engage in learning knowledge to solve problems. Consistent with the above assertions, H8 was positively supported, indicating that epistemic curiosity plays a mediating role between creative self-efficacy and STEM knowledge acquired in fashion design.

According to the information-processing theory, individuals respond to changes in their surroundings, leading to the development of feelings of competence and mastery (White, 1959). Curiosity can stimulate the individual to explore new ideas to foster novelty and aesthetic performance (Wu, 2015; Wu \& Miao, 2013). Hardy III et al. (2017) highlighted that the product design activity has the I-type EC tendency because it is the early stage of design, and requires that individuals gather a wide range of information relevant to the design issues so that they can generate and evaluate new ideas. On the other hand, individuals higher in D-type EC will be more motivated to develop more ideas related to the idea evaluation and implementation stages of practical performance (Hardy III et al., 2017). The findings of this study supported those of Hardy III et al. (2017), indicating that the I-type of EC was helpful for creativity; consequently, H9, H10, and H11 were positively supported in this study. However, Hardy III et al. (2017) reported that D-type EC was unrelated to creative performance while performing tasks to solve complex problems. Consistent with their assertion, the results of this study revealed that D-type EC was positively related to three types of creative performance; in particular, comparing the correlation coefficient levels of D-type to those of I-type EC, D-type EC was much higher for utility $\left(.181^{* *}\right.$ vs $\left..062^{*}\right)$ and aesthetics $\left(.185^{* *}\right.$ vs. $\left..074^{*}\right)$. The reason may be due to the fact that quality improvement is required in the processes of fashion design, leading to more work to solve problems to make the bag design look beautiful and useful. Thus, H12, H13, and H14 were positively supported.

Byrge and Tang (2015) reported that embodied creativity training can foster trainees' CSE and creative production, and found a positive relationship between CSE and creative production. Karwowski (2011) noted that CSE had a positive relationship between Polish secondary students' CSE and their creative ability. When applying STEM to project design, it has been revealed that participants with higher level CSE can perform better (Yang \& Cheng, 2009); in other words, good CSE can facilitate a sense of knowledge inquiry (Tierney \& Farmer, 2002; Mathisen \& Bronnick, 2009), in which the value of the creative work can be upgraded (Tierney \& Farmer, 2011), the utility can be improved ( $\mathrm{Li}$, Wang, \& Li, 2007), and the aesthetics can be enriched (Wu, 2015). Thus, H15 was positively supported.

\section{CONCLUSIONS}

Based on the self-compassion theory, a research model was designed in this study for verification. The experimental results verified that the research model, which incorporates STEM into the application of fashion design, can effectively influence the learning of STEM knowledge and improve the creative performance of those designers who have a high level of CSE and epistemic curiosity. Briefly, there were positive correlations among creative self-efficacy, EC, and Creative performance. Taken together, if the STEM concept can be applied to the fashion design field, it will be helpful for the integration of all aspects of STEM into fashion design learning. 
To enable a "STEM of practice" in design education, in this study we developed a framework for studying STEM learning in bag design. As part of the development of this "STEM of practice," as a starting point, based on the purpose and theories of this study, STEM was integrated into a design course as pedagogical practice for the students. From the results of this study, we believe that there are a number of perspectives and suggestions with regard to STEM education. First, eliminating the present barriers to teaching STEM is critical. If we hope to raise the level of integration of STEM, design courses should emphasize STEM knowledge inquiry in the way of design practice. There is then a need for design-led teachers to use the teaching procedure presented in this study in different disciplinary areas and curricula other than fashion design.

Second, the results of this study indicate that STEM knowledge learning plays a key role in creative performance in the domain of fashion design. STEM is becoming universal, but is generally not applied in design education. It is recommended that fashion design teachers can adopt a view that integrates STEM into design practice in the classroom, to enrich students' ability in the connections between the STEM knowledge they learn, and the practice of design they are encouraged to initiate. In this way, students can become actively engaged in problem-solving, creating concepts to "transfer-in-pieces" to complete design work that can anchor individual meaningful learning.

Regarding future study, novelty, utility, and aesthetics are essential dimensions of fashion design; however, there are many other definitions of creative performance in relation to different types of product design that should be reconsidered to explore in the application of STEM. Because STEM in different types of product design involves different material properties, process methods, engineering approaches, and mathematical measurements, teachers should be trained in identifying elements of STEM and creative performance for the particular product design to ensure that students can learn the related knowledge to improve their creative performance.

There is another issue relevant to gender difference in STEM education that has been argued for decades. A previous study considered that female students are not so interested in studying the engineering area of STEM compared to male students (Kulturel-Konak, D'Allegro, \& Dickinson, 2011), but few studies have considered the gender issue in learning STEM in fashion design. This interesting topic was not analyzed in this study, but future studies can examine differences between male and female students' two types of epistemic curiosity in fashion design and how they influence their creative performance.

Finally, this study is based on quantification-based validation, therefore, this study uses qualitative research methods to explore the utility of STEM for fashion design, and in subsequent studies will be added to the interview method to understand the fashion design learner's idea of STEM, in addition, the STEM indicators in fashion design can be better classified through expert meeting. At present, the STEM curriculum for fashion design has only begun to develop, so the complete series of courses has not yet been developed in this study. In the follow-up study, this study suggests that different teaching methods can be combined into the STEM curriculum development in fashion design.

\section{ACKNOWLEDGEMENT}

This work was financially supported by the “Institute for Research Excellence in Learning Sciences" of National Taiwan Normal University (NTNU) from The Featured Areas Research Center Program within the framework of the Higher Education Sprout Project by the Ministry of Education (MOE) in Taiwan and Ministry of Science and Technology, Taiwan, R.O.C. under Grant no. MOST 107-2511-H-003 -019.

\section{REFERENCES}

Aladé, F., Lauricella, A. R., Beaudoin-Ryan, L., \& Wartella, E. (2016). Measuring with murray: Touchscreen technology and preschoolers' STEM learning. Computers in Human Behavior, 62, 433-441. https:/ / doi.org/10.1016/j.chb.2016.03.080

Ashby, M., Shercliff, H., \& Cebon, D. (2007). Materials engineering, science, processing and design. Oxford, UK: Elsevier.

Bakhshi, H., Hargreaves, I., \& Mateos-Garcia, J. (2013). A manifesto for the creative economy: Resource document. London, UK: Nesta. https://www.nesta.org.uk/publications/manifesto-creative-economy

Bandura, A. (1977). Self-efficacy: toward a unifying theory of behavioral change. Psychological Review, 84(2), 191215. https:/ / doi.org/10.1037/0033-295X.84.2.191

Beeftink, F., Van Eerde, W., Rutte, C. G., \& Bertrand, J. W. M. (2012). Being successful in a creative profession: The role of innovative cognitive style, self-regulation, and self-efficacy. Journal of Business and Psychology, 27(1), 71-81. https:// doi.org/10.1007/s10869-011-9214-9

Beghetto, R. A. (2016). Creative learning: A fresh look. Journal of Cognitive Education and Psychology, 15, 6-23. https://doi.org/10.1891/1945-8959.15.1.6 
Bell, D. (2016). The reality of STEM education, design and technology teachers' perceptions: A phenomenographic study. International Journal of Technology and Design Education, 26(1), 61-79. https:// doi.org/10.1007/s10798015-9300-9

Berlyne, D. E. (1960). Conflict, arousal, and curiosity. New York, NY: McGraw-Hill Book. https://doi.org/10.1037/ 11164-000

Berlyne, D. E. (1966). Curiosity and exploration. Science, 153, 25-33. https:/ / doi.org/10.1126/science.153.3731.25

Besemer, S. P., \& O'Quin, K. (1999). Confirming the three-factor creative product analysis matrix model in an American sample. Creativity Research Journal, 12, 287-296. https:/ / doi.org/10.1207/s15326934crj1204_6

Bybee, R. W. (2010). Advancing STEM education: A 2020 vision, Technol. Teach, 70 (1), 30-35.

Byrge, C., \& Tang, C. (2015). Embodied creativity training: Effects on creative self-efficacy and creative production. Thinking Skills and Creativity, 16, 51-61. https:/ / doi.org/10.1016/j.tsc.2015.01.002

Caprara, G. V., Giunta, L. D., Eisenberg, N., Gerbino, M., Pastorelli, C., \& Tramontano, C. (2008). Assessing regulatory emotional self-efficacy in three countries. Psychological Assessment, 20, 227-237. https:/ / doi.org/10.1037/1040-3590.20.3.227

Cheng, V. M.Y. (2016). Understanding and enhancing personal transfer of creative learning. Thinking Skills and Creativity, 22, 58-73. https:/ / doi.org/10.1016/j.tsc.2016.09.001

Chin, W. W. (1998). The partial least squares approach to structural equation modeling. Modern Methods for Business Research, 295(2), 295-336.

Christiaans, H. C. M.(2002). Creativity as a design criterion. Creativity Research Journal, 14(1), 41-54. https://doi.org/10.1207/S15326934CRJ1401_4

Claxton, G., Edwards, L., \& Scale-Constantinou, V. (2006). Cultivating creative mentalities: A framework for education. Thinking Skills and Creativity, 1(1), 57-61. https:/ / doi.org/10.1016/j.tsc.2005.11.001

Clinton, G., \& Hokanson, B. (2012). Creativity in the training and practice of instructional designers: The design/creativity loops model. Educational Technology Research and Development, 60(1), 111-130. https:/ / doi.org/10.1007/s11423-011-9216-3

Cor, M. K. (2016). Trust me, it is valid: Research validity in pharmacy education research. Currents in Pharmacy Teaching and Learning, 8(3), 391-400. https:/ / doi.org/10.1016/j.cpt1.2016.02.014

Cross, N. (2006). Designerly ways of knowing (Vol. 1). London, UK: Springer. https:/ / doi.org/10.1007/1-84628- 3019

Daly, S. R., Mosyjowski, E. A., \& Seifert, C. M. (2014). Teaching creativity in engineering courses. Journal of Engineering Education, 103, 417-449. https://doi.org/10.1002/jee.20048

Duch, W. (2007). Creativity and the brain. In A. G. Tan (Ed.), A handbook of creativity for teachers (pp. 507-530). Singapore, SG: World Scientific Publishing. https:/ / doi.org/10.1142/9789812770868_0027

Dweck, C. S. (2000). Self-theories: Their role in motivation, personality, and development. New York, NY: Psychology Press.

Dweck, C. S., \& Leggett, E. L. (1988). A social-cognitive approach to motivation and personality. Psychological Review, 95, 256-273. https:/ / doi.org/10.1037/0033-295X.95.2.256

Fan, S. C., \& Yu, K. C. (2017). How an integrative STEM curriculum can benefit students in engineering design practices. International Journal of Technology and Design Education, 27(1), 107-129. https:/ / doi.org/10.1007/s10798-015-9328-x

Finke, R., Ward, T., \& Smith, S. (1992). Creative cognition: Theory, research and applications. Cambridge, UK: MIT Press.

Fleischhauer, M., Enge, S., Brocke, B., Ullrich, J., Strobel, A., \& Strobel, A. (2010). Same or different? Clarifying the relationship of need for cognition to personality and intelligence. Personality and Social Psychology Bulletin, 36(1), 82-96. https:/ / doi.org/10.1177/0146167209351886

Fornell, C. R., \& Larcker, F. F. (1981). Structural equation models with unobservable variables and measurement error. Journal of Marketing Research, 18, 39-51.

Gajda, A., Beghetto, R. A., \& Karwowski, M. (2017). Exploring creative learning in the classroom: A multi-method approach. Thinking Skills and Creativity, 24, 250-267. https://doi.org/10.1016/j.tsc.2017.04.002

Goldberg, S., Gibbs, A., Caro-Aguado, B. M., \& Munoz, M. (2015). Enhancement of memory through curiositydriven learning. Eukaryon, 11. Retrieved from http://www.lakeforest.edu/live/files/2701goldberggibbscaro-aguadomunozenhancementpdf

Gomez, A., \& Albrecht, B. (2013). True STEM education. Technology and Engineering Teacher, 73(4), 8-16. 
Green, S. B., \& Salkind, N. (2004). Using SPSS for Windows and Macintosh: Analyzing and understanding data (4th ed.). Englewood Cliffs, NJ: Prentice-Hall.

Guilford, J. P. (1967). The nature of human intelligence. New York, NY: McGraw-Hill.

Gulten, D. C., Yaman, Y., Deringol, Y., \& Ozsari, I. (2011). Investigating the relationship between curiosity level and computer self-efficacy beliefs of elementary teachers candidates. Turkish Online Journal of Educational Technology - TOJET, 10(4), 248-254.

Hair, J. F., Black, W.C., Babin, B.J. \& Anderson, R.E. (2010). Anderson multivariate data analysis (7th ed.), Upper Saddle River, NJ: Pearson Prentice Hall.

Hair, J. F., Sarstedt, M., Ringle, C. M., \& Henseler, J. (2012). On the emancipation of PLS-SEM: A commentary on Rigdon. Long Range Planning, 47(3), 154-160.

Hall, A., \& Miro, D. (2016). A study of student engagement in project-based learning across multiple approaches to STEM education programs. School Science and Mathematics, 116(6), 310-319. https://doi.org/10.1111/ssm.12182

Han, S., Capraro, R. M., \& Capraro, M. M. (2016). How science, technology, engineering, and mathematics project based learning affects high-need students in the U.S. Learning and Individual Differences, 51, 157-166. https:/ / doi.org/10.1016/j.lindif.2016.08.045

Hancock, G. R., \& Mueller, R. O. (Eds.)(2006). Structural equation modeling: A second course. Greenwich, CT: Information Age Publishing, Inc. https://doi.org/10.1207/s15328007sem1303_2

Hardy III, J. H., Ness, A. M., \& Mecca, J. (2017). Outside the box: Epistemic curiosity as a predictor of creative problem solving and creative performance. Personality and Individual Differences, 104, 230-237. https://doi.org/10.1016/j.paid.2016.08.004

Harrison, R. L., \& Parks, B. (2017). How STEM can gain some STEAM: Crafting meaningful collaborations between STEM disciplines and inquiry-based writing programs. In A. J. Myatt, \& L. L. Gaillet (Eds.), Writing program and writing center collaborations (pp. 117-139). New York, NY: Palgrave Macmillan. https://doi.org/10.1057/978-1-137-59932-2_6

Harrison, S. H., Sluss, D. M., \& Ashforth, B. E. (2011). Curiosity adapted the cat: The role of trait curiosity in newcomer adaptation. Journal of Applied Psychology, 96, 211-220. https:/ / doi.org/10.1037/a0021647

Hartnett, E.J., Malzahn, N., \& Goldsmith, R. (2014). Video performances juxtaposing STEM with creativity. In C. Rensing, S. de Freitas, T. Ley, \& P. J. Munoz-Merino (Eds.), Open Learning and Teaching in Educational Communities (pp. 570-571). EC-TEL 2014. Lecture notes in computer science (Vol. 8719). Cham, CH: Springer. https:/ / doi.org/10.1007/978-3-319-11200-8_74

Hathcock, S. J., Dickerson, D. L., Eckhoff, A., \& Katsioloudis, P. (2015). Scaffolding for creative product possibilities in a design-based STEM activity. Research in Science Education, 45(5), 727-748. https:/ / doi.org/10.1007/s11165-014-9437-7

Horzyk, A. (2014). How does generalization and creativity come into being in neural associative systems and how does it form human-like knowledge? Neurocomputing, 144, 238-257. https:/ / doi.org/10.1016/j.neucom.2014.04.046

Huang, Y., \& Li, J. (2015). Comparing personal characteristic factors of imagination between expert and novice designers within different product design stages. International Journal of Technology and Design Education, 25, 261-292. https:/ / doi.org/10.1007/s10798-014-9276-x

Ito, M., Gutiérrez, K., Livingstone, S., Penuel, B., Rhodes, J., Salen, K., Schor, J., Sefton-Green, J, \& Watkins, S. C. (2013). Connected learning: An agenda for research and design. Irvine, CA: Digital Media and Learning Research Hub.

Jeraj, M., \& Marič, M. (2013). Relation between entrepreneurial curiosity and entrepreneurial self-efficacy: A multicountry empirical validation. Organizacija, 46, 264-273. https://doi.org/10.2478/orga-2013-0027

Johnson, E. A., \& O'Brien, K. A. (2013). Self-compassion soothes the savage EGO-threat system: Effects on negative affect, shame, rumination, and depressive symptoms. Journal of Social and Clinical Psychology, 32(9), 939-963. https://doi.org/10.1521/jscp.2013.32.9.939

Jovanović, V., \& Brdaric, D. (2012). Did curiosity kill the cat? Evidence from subjective well-being in adolescents. Personality and Individual Differences, 52(3), 380-384. https:/ / doi.org/10.1016/j.paid.2011.10.043

Kaldi, S., Filippatou, D., \& Govaris, C. (2011). Project-based learning in primary schools: Effects on pupils' learning and attitudes. Education 3-13: International Journal of Primary, Elementary and Early Years Education, 39(1), 3547. https:// doi.org/10.1080/03004270903179538 
Kang, M. J., Hsu, M., Krajbich, I. M., Loewenstein, G., McClure, S. M., Tao-yi Wang, J., \& Camerer, C. F. (2009). The wick in the candle of learning: Epistemic curiosity activates reward circuitry and enhances memory. Psychological Science, 20(8), 963-973. https:// doi.org/10.1111/j.1467-9280.2009.02402.x

Karwowski, M. (2011). Doesn't hurt to ask . . . but sometimes it hurts to believe: Polish students' creative selfefficacy and its predictors. Psychology of Aesthetics, Creativity, and the Arts, 5(2), 154-164. https:/ / doi.org/10.1037/a0021427

Karwowski, M. (2012). Relationship between trait curiosity, creative self-efficacy and creative personal identity. Europe's Journal of Psychology, 8(4), 547. https://doi.org/10.5964/ejop.v8i4.513

Karwowski, M. (2017). Subordinated and rebellious creativity at school. In. R. A. Beghetto \& B. Sriraman (Eds.), Creative contradictions in education (pp. 89-115). Cham, CH: Springer. https://doi.org/10.1007/978-3-31921924-0_6

Khedhaouria, A., Montani, F., \& Thurik, R. (2017). Time pressure and team member creativity within R\&D projects: The role of learning orientation and knowledge sourcing. International Journal of Project Management, 35(6), 942-954. https:/ / doi.org/10.1016/j.ijproman.2017.04.002

Kim, K. H. (2006). Can we trust creativity tests? a review of the Torrance tests of creative thinking (TTCT). Creativity Research Journal, 18, 3-14. https://doi.org/10.1207/s15326934crj1801_2

Kulturel-Konak, S., D’Allegro, M. L., \& Dickinson, S. (2011). Review of gender differences in learning styles: Suggestions for stem education. Contemporary Issues in Education Research, 4(3), 9-18. https:/ / doi.org/10.19030/ cier.v4i3.4116

Langdon, D., McKittrick, G., Beede, D., Khan, B., \& Doms, M. (2011). STEM: Good jobs now and for the future. Retrieved from http://www.esa.doc.gov/sites/default/files/stemfinalyjuly14_1.pdf

Lauriola, M., Litman, J. A., Mussel, P., De Santis, R., Crowson, H. M., \& Hoffman, R. R. (2015). Epistemic curiosity and self-regulation. Personality and Individual Differences, 83, 202-207. https:/ / doi.org/10.1016/j.paid.2015.04.017

León, J., Núñez, J. L., \& Liew, J. (2015). Self-determination and STEM education: Effects of autonomy, motivation, and self-regulated learning on high school math achievement. Learning and Individual Differences, 43, 156163. https:// doi.org/10.1016/j.lindif.2015.08.017

Li, C., \& Wu, J. (2011). The structural relationships between optimism and innovative behavior: Understanding potential antecedents and mediating effects. Creativity Research Journal, 23(2), 119-128. https:/ / doi.org/10.1080/10400419.2011.571184

Li, Y., Wang, J., \& Li, X. (2007). Design creativity in product innovation. The International Journal of Advanced Manufacturing Technology, 33(3), 213-222. https:/ / doi.org/10.1007/s00170-006-0457-y

Litman, J. A. (2005). Curiosity and the pleasures of learning: Wanting and liking new information. Cognition and Emotion, 19, 793-814. https:/ / doi.org/10.1080/02699930541000101

Litman, J. A. (2008). Interest and deprivation factors of epistemic curiosity. Personality and Individual Differences, 44, 1585-1595. https://doi.org/10.1016/j.paid.2008.01.014

Litman, J. A. (2014). Cross cultural validity of the interest- and deprivation-type epistemic curiosity model: Findings from three German samples. Personality and Individual Differences, 60, S8. https:/ / doi.org/10.1016/j.paid.2013.07.172

Litman, J. A., \& Jimerson, T. L. (2004). The measurement of curiosity as a feeling of deprivation. Journal of Personality Assessment, 82, 147-157. https://doi.org/10.1207/s15327752jpa8202_3

Litman, J. A., \& Silvia, P. J. (2006). The latent structure of trait curiosity: Evidence for interest and deprivation curiosity dimensions. Journal of Personality Assessment, 86, 318-328. https://doi.org/10.1207/s15327752jpa8603_07

Litman, J. A., \& Spielberger, C. D. (2003). Measuring epistemic curiosity and its diversive and specific components. Journal of Personality Assessment, 80, 75-86. https:/ / doi.org/10.1207/S15327752JPA8001_16

Lobato, J. (2012). The actor-oriented transfer perspective and its contributions to educational research and practice. Educational Psychologist, 47(3), 232-247. https:/ / doi.org/10.1080/00461520.2012.693353

Lou, S.-J., Liu, Y.-H., Shih, R.-C., Chuang, S.-Y., \& Tseng, K.-H. (2011). Effectiveness of on-line STEM project-based learning for female senior high school students. International Journal of Engineering Education, 27(2), 399-410.

MacCallum, R. C., Browne, M. W., \& Sugawara, H. M. (1996). Power analysis and determination of sample size for covariance structure modeling. Psychological Methods, 1, 130-149. https:/ / doi.org/10.1037/1082-989X.1.2.130

Markham, T. (2003). Project based learning handbook: A guide to standards-focused project based learning for middle and high school teachers. Novato, CA: Buck Institute for Education. 
Martin, A. J. (2015). Implicit theories about intelligence and growth (personal best) goals: Exploring reciprocal relationships. British Journal of Educational Psychology, 85, 207-223. https:/ / doi.org/10.1111/bjep.12038

Mathisen, G. E., \& Bronnick, K. S. (2009). Creative self-efficacy: An intervention study. International Journal of Educational Research, 48(1), 21-29. https://doi.org/10.1016/j.ijer.2009.02.009

Miller, B. G., \& Roehrig, G. (2018). Indigenous cultural contexts for STEM experiences: Snow snakes' impact on students and the community. Cultural Studies of Science Education, 13(1), 31-58. https:/ / doi.org/10.1007/s11422-016-9738-4

Moye, J. J., Dugger, W. E., \& Stark-Weather, K. N. (2014). Learning by doing: Research introduction. Technology and Engineering Teacher, 74(1), 24-27.

Mussel, P. (2013). Introducing the construct curiosity for predicting job performance. Journal of Organizational Behavior, 34, 453-472. https:/ / doi.org/10.1002/job.1809

Puente-Díaz, R., \& Cavazos-Arroyo, J. (2017). The influence of creative mindsets on achievement goals, enjoyment, creative self-efficacy and performance among business students. Thinking Skills and Creativity, 24, 1-11. https:// doi.org/10.1016/j.tsc.2017.02.007

Robbins, T. L., \& Kegley, K. (2010). Playing with thinker toys to build creative abilities through online instruction. Thinking Skills and Creativity, 5, 40-48. https:/ / doi.org/10.1016/j.tsc.2009.07.001

Satchwell, R. E., \& Loepp, F. L. (2002). Designing and implementing an integrated mathematics, science, and technology curriculum for the middle school. Journal of Industrial Teacher Education, 39(3), 1-15.

Sawyer, R. K. (2015). A call to action: The challenges of creative teaching and learning. Teachers College Record, 117(100303), 1-34.

Shapira, L. B., \& Mongrain, M. (2010). The benefits of self-compassion and optimism exercises for individuals vulnerable to depression. The Journal of Positive Psychology 5(5), 377-389. https:/ / doi.org/10.1080/17439760.2010.516763

Stolarova, M., Wolf, C., Rinker, T., \& Brielmann, A. (2014). How to assess and compare inter-rater reliability, agreement and correlation of ratings: An exemplary analysis of mother-father and parent-teacher expressive vocabulary rating pairs. Frontiers in Psychology, 5, 509. https:/ / doi.org/10.3389/fpsyg.2014.00509

Sullivan, A., \& Bers, M. U. (2016). Robotics in the early childhood classroom: Learning outcomes from an 8-week robotics curriculum in pre-kindergarten through second grade. International Journal of Technology and Design Education, 26(1), 3-20.

Tierney, P., \& Farmer, S. M. (2002). Creative self-Efficacy: Its potential antecedents and relationship to creative performance. The Academy of Management Journal, 45(6), 1137-1148.

Tierney, P., \&Farmer, S. M. (2011). Creative self-efficacy development and creative performance over time. Journal of Applied Psychology, 96(2), 277-293. https:// doi.org/10.1037/a0020952

Torrance, E. P. (1966). The Torrance Tests of Creative Thinking: Norms-technical manual (research edition). Princeton, NJ: Personnel Press.

US Bureau of Labor Statistics (2019). Occupational outlook handbook. Retrieved from http:/ /www.bls.gov/ooh/artsand-design/fashion-designers.htm

van Aalderen-Smeets, S. I., \& Walma van der Molen, J. H. (2018). Modeling the relation between students' implicit beliefs about their abilities and their educational STEM choices. International Journal of Technology and Design Education, 28, 1-27. https:/ / doi.org/10.1007/s10798-016-9387-7

Vogt, W. P. (2007). Quantitative research methods for professionals. Boston, MA: Pearson Education, Inc.

Wagner, J. F. (2006). Transfer in pieces. Cognition and Instruction, 24, 1-71. https://doi.org/10.1207/s1532690xci2401_1

Wagner, J. F. (2010). A transfer-in-pieces consideration of the perception of structure in the transfer of learning. The Journal of the Learning Sciences, 19, 443-479. https:/ / doi.org/10.1080/10508406.2010.505138

Wai, J., Lubinski, D., \& Benbow, C. P. (2009). Spatial ability for STEM domains: Aligning over 50 years of cumulative psychological knowledge solidifies its importance. Journal of Educational Psychology, 101(4), 817-835. https:/ / doi.org/10.1037/a0016127

Wang, S., Zhang, X., \& Martocchio, J. (2011). Thinking outside of the box when the box is missing: Role ambiguity and its linkage to creativity. Creativity Research Journal, 23(3), 211-221. https:/ / doi.org/10.1080/10400419.2011.595661

Ward, J. R., Clarke, H. D., \& Horton, J. L. (2014). Effects of a research-infused botanical curriculum on undergraduates' content knowledge, STEM competencies, and attitudes toward plant sciences. CBE - Life Sciences Education, 13(3), 387-396. https:/ / doi.org/10.1187/cbe.13-12-0231 
Warr, A., \& O'Neill, E. (2005). Understanding design as a social creative process. In E. Edmonds (Ed.), Proceedings of the 5th Conference on Creativity and Cognition (pp. 118-127). London, UK: ACM. https://doi.org/10.1145/1056224.1056242

White, R. W. (1959). Motivation reconsidered: The concept of competence. Psychological Review, 66, $297-333$. https://doi.org/10.1037/h0040934

Williams, J., Jones, A., \& Bunting, C. (2015). The future of technology education. Singapore, SG: Springer. https:// doi.org/10.1007/978-981-287-170-1

Workosky, C., \& Willard, T. (2015). Answers to teachers' questions about the next generation science standards. Science Teacher, 82(6), 29-31. https:/ / doi.org/10.2505/4/tst15_082_06_29

World Economic Forum. (2015). New vision for education: Unlocking the potential of technology: Resource document. Geneva, $\quad \mathrm{CH}$ : World Economic https://www3.weforum.org/docs/WEFUSA_NewVisionforEducation_Report2015.pdf

Worsham, E. K., Clevenger, A., \& Whealan-George, K. A.(2016). STEM education discrepancy in the united states and Singapore. Beyond, 1, 20-26.

Wright, N., \& Wrigley, C. (2019). Broadening design-led education horizons: Conceptual insights and future research directions. International Journal of Technology and Design Education, 29, 1-23. https:/ / doi.org/10.1007/s10798- 017-9429-9

Wu, C.-C. (2002). Chinese students to explore and cultivate creativity. The Application of Psychological Research, 15, $17-22$.

$\mathrm{Wu}, \quad \mathrm{Q}$ (2015). Computational curiosity (a book draft). Retrieved from https://arxiv.org/ftp/arxiv/ papers/1502/1502.04780.pdf

Wu, Q., \& Miao, C. (2013). Curiosity: From psychology to computation. ACM Computing Surveys, 46(2), 18:1-18:26.

Yang, H. L., \& Cheng, H. H. (2009). Creative self-efficacy and its factors: An empirical study of information system analysts and programmers. Computers in Human Behavior, 25(2), 429-438. https://doi.org/10.1016/j.chb.2008.10.005

Zeisel, J. (2006). Inquiry by design: Environment/Behavior/Neuroscience in architecture, interiors, landscape and planning (2nd ed.). New York, NY: Norton.

Zhang, L. (2019). "Hands-on" plus “inquiry"? Effects of withholding answers coupled with physical manipulations on students' learning of energy-related science concepts. Learning and Instruction, 60, 199-205. https://www.sciencedirect.com/science/article/pii/S0959475217305455?via\%3Dihub

Zollman, A. (2012). Learning for STEM literacy: STEM literacy for learning. School Science and Mathematics, 112(1), 12-19. https:// doi.org/10.1111/j.1949-8594.2012.00101.x 
APPENDIX A

Bag Designs
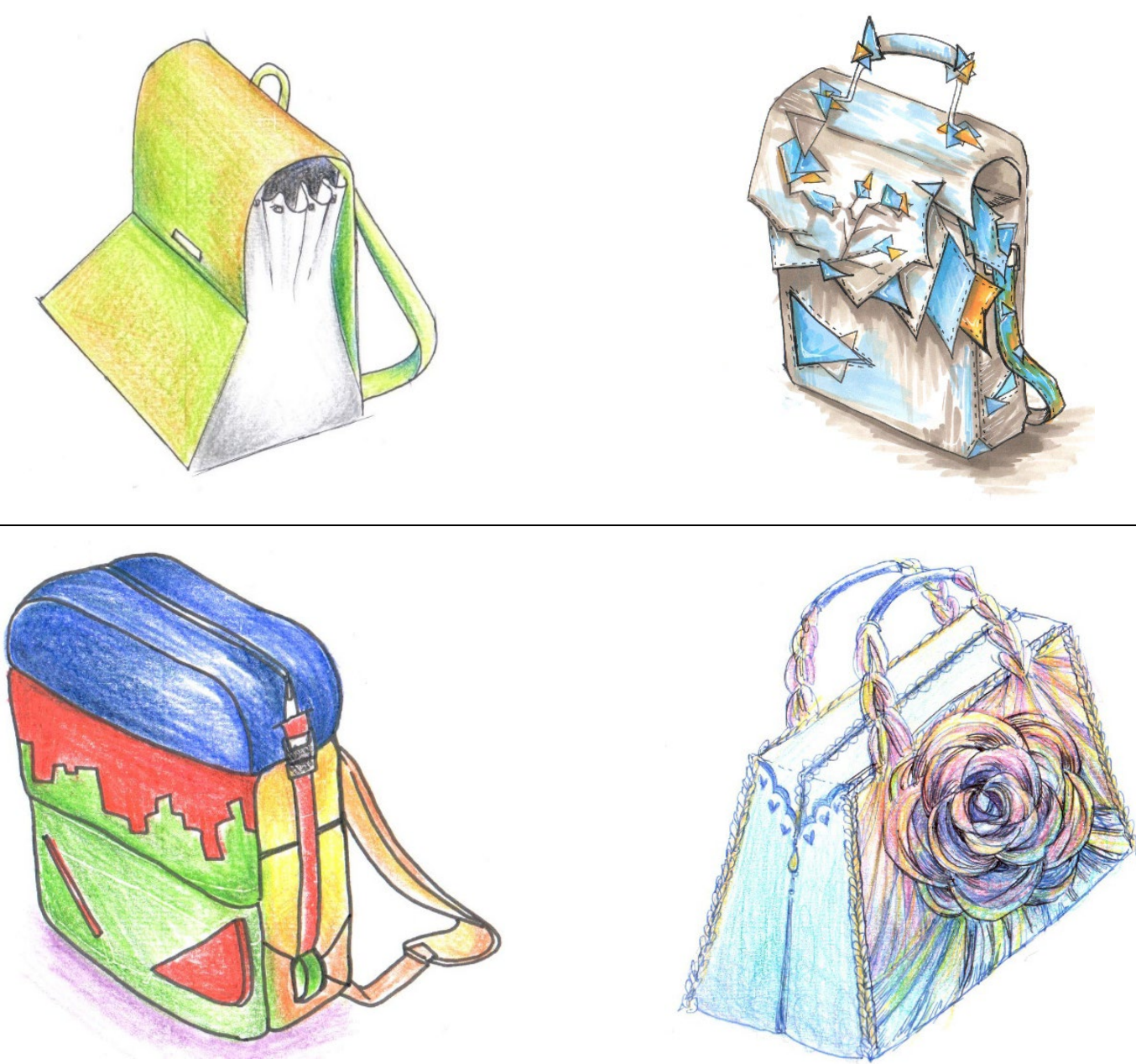

http://www.ejmste.com 